\title{
Response to Comments Made on "Alternative Rhinoplasty Technique: Rotational Spreader Flap (Rabbit Flap)”
}

\author{
Ali Ahmet $\operatorname{Sirin}^{1} \cdot$ Ibrahim Erdim ${ }^{2}$ (B)
}

Received: 22 January 2018/Accepted: 25 January 2018/Published online: 1 February 2018

(C) Springer Science+Business Media, LLC, part of Springer Nature and International Society of Aesthetic Plastic Surgery 2018

Level of Evidence $V$ This journal requires that authors assign a level of evidence to each article. For a full description of these Evidence-Based Medicine ratings, please refer to the Table of Contents or the online Instructions to Authors www.springer.com/00266.

Dear Sir,

We were pleased to read the comment on our study entitled: "An Alternative Rhinoplasty Technique: Rotational Spreader Flap (Rabbit Flap)" [1]. First, we did in fact cite the paper of Bohluli et al., who first described the technique [2]. We used the adjective "alternative" rather than "novel". The paper of Bohluli et al. appeared in 2013 [2]. Unfortunately, 1 year later, Kuran et al. and Bertossi et al. described identical techniques, mistakenly describing them as "novel" [3, 4]. Ozucer and Ozturan [5] did comment that this was inappropriate, but Kuran et al. [6] did not respond in a substantive manner. Gruber described the cephalic part of the lower lateral cartilage as "the tails of the lateral crus", but the details remain those of Bohluli et al. $[2,7]$.

As your correspondent opined, our study is essentially methodological in nature. We objectively measured both the nasolabial and nasal axis angles preoperatively, and no earlier than 1 year post-operatively. Patient satisfaction is critical when evaluating rhinoplastic outcomes. We thus

Ibrahim Erdim

ibrahim_erdim@hotmail.com

Uzmanlar Health Center, Istanbul, Turkey

2 Medical Faculty, Gaziosmanpasa University, Kaleard1, Mahallesi Muhittin Fisunoğlu Caddesi Ali Sevki EREK Yerleskesi, 60100 Tokat, Turkey asked all patients to complete rhinoplastic outcome questionnaires both pre- and post-operatively.

We agree that the technique must be enshrined in textbooks, and given a unique descriptor to prevent confusion. We thank the correspondents for their useful comments.

\section{Compliance with Ethical Standards}

Conflict of interest The author declares that he has no conflicts of interest to disclose.

\section{References}

1. Sirin AA, Erdim I, Erdur O, Sirin A (2017) An alternative rhinoplasty technique: rotational spreader flap ("rabbit flap"). Aesthetic Plast Surg. https://doi.org/10.1007/s00266-017-0999-4

2. Bohluli B, Varedi P, Nazari S, Bagheri SC (2013) Lateral crural suspension flap: a novel technique to modify and stabilize the nasolabial angle. J Oral Maxillofac Surg 719:1572-1576

3. Kuran I, Öreroğlu AR, Efendioğlu K (2014) The lateral crural rein flap: a novel technique for management of tip rotation in primary rhinoplasty. Aesthet Surg J 34(7):1008-1017

4. Bertossi D, Walter C, Nocini PF (2014) The pull-up spreader high (PUSH) technique for nasal tip support. Aesthet Surg J 34(8): 1153-1161

5. Ozucer B, Ozturan O (2015) Comments on "The lateral crural rein flap: a novel technique for management of tip rotation in primary rhinoplasty". Aesthet Surg J 35(5):NP125

6. Kuran I, Öreroğlu AR, Efendioğlu K (2015) Response to "Comments on 'The lateral crural rein flap: a novel technique for management of tip rotation in primary rhinoplasty"'. Aesthet Surg J 35(5):NP126

7. Gruber RP (1993) Primary open rhinoplasty. In: Gruber RP, Peck GC (eds) Rhinoplasty: state of the art. Mosby Year Book, St Louis, MO, pp 61-68 